\title{
Juvenile Xanthogranulomata in a One and a Half-Year-Old Boy
}

\author{
Received: May 10, 2016 Accepted: August 30, 2016 \\ doi: http://dx.doi.org/10.3329/jemc.v6i3.29687
}

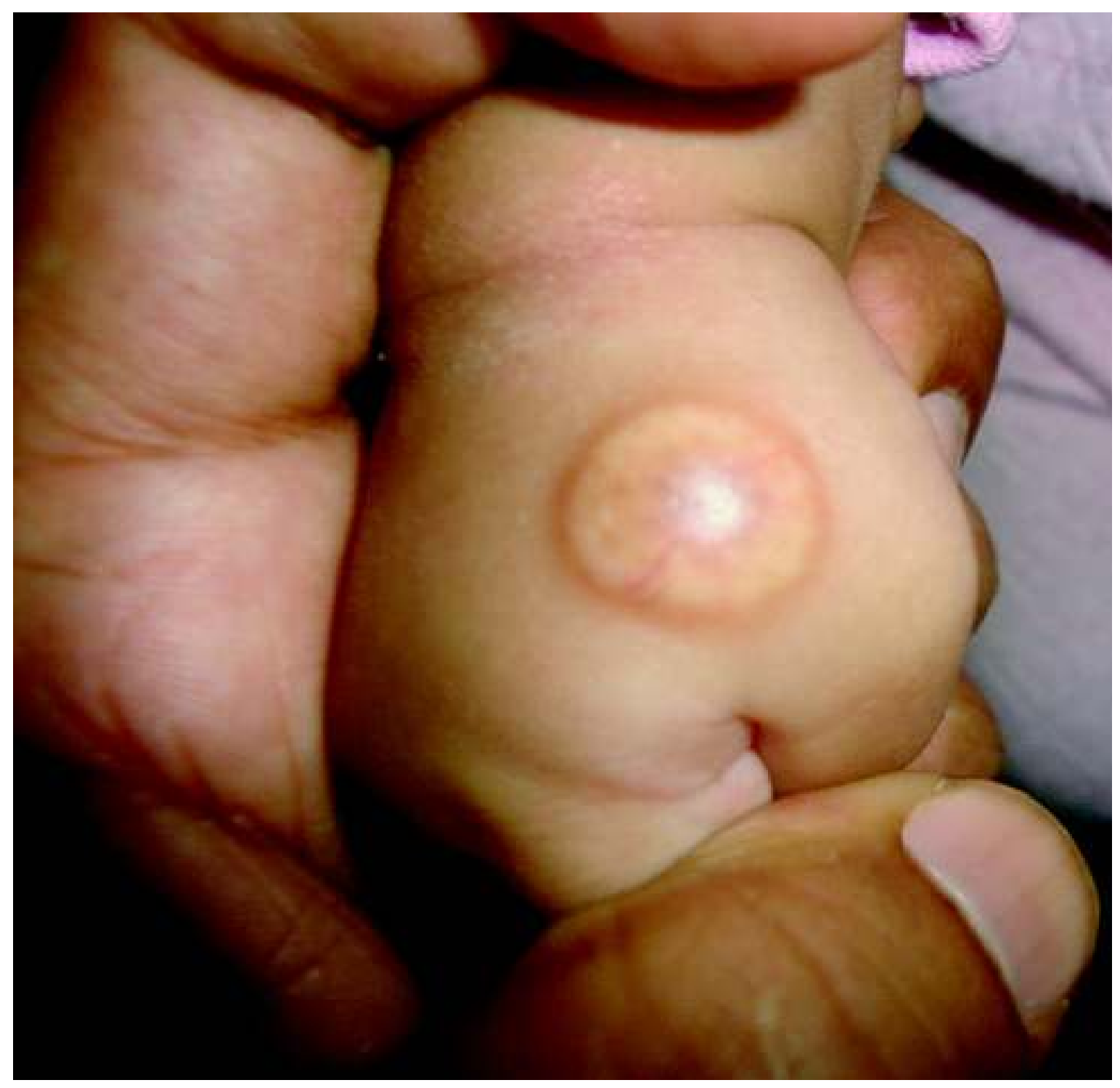

A one and a half-year-old boy presented in the Department of Dermatology and Venereal Disease with a solitary nodular lesion on the dorsum of the right hand for one month. The nodule was well demarcated, firm and rubbery in consistency, $16 \mathrm{~mm}$ $\times 10 \mathrm{~mm}$ in size and yellow in color with central ulceration. A $3 \mathrm{~mm}$ punch biopsy from the lesion was taken. Histopathology of the nodule revealed circumscribed proliferation of foamy histiocytes, vacuolated and multinucleated giant cells named Touton cells, eosinophillic cytoplasmic center and peripheral xanthomatization. All these features were consistent with juvenile xanthogranulomata. The patient was under clinical observation without any treatment. After three and a half years, the lesion disappeared leaving a mildly hyperpigmented area.

Juvenile xanthogranulomata $(\mathrm{JXG})$ is a rare benign 
cutaneous fibrohistiocystic disease and usually presents during infancy and early childhood. ${ }^{1}$ It is a member of the non-Langerhans cell group of histiocytic proliferative disorders. ${ }^{2}$ It was first reported by H.G. Adamson in $1905 .^{3}$ In children the male female ratio of cutaneous JXG is about 1.4:1 and in adults there is no sex predilection. ${ }^{4}$ JXG is characterized by one or more cutaneous nodules and occasionally presence of lesions in the deeper soft tissue and organs. Head, neck and trunk are the most common sites, but may also be on groin, scrotum, penis, clitoris, eyelid, toenail, palms, soles and lips. ${ }^{5}$ Differential diagnoses of JXG are molluscum contagiosum, spitz nevi, mastocytomas, hemangioma and neurofibroma.

Histopathology of JXG shows well-circumscribed nodules with dense infiltration of histiocytes. In case of cutaneous lesion, dermis is usually involved. Touton giant cells characterized by a wreath of nuclei around a homogenous eosinophillic cytoplasmic center and xanthomatization in the periphery are seen in $85 \%$ cases. $^{2}$ Fibrosis may be present in older regressing lesions.

Immunohistochemical findings are important to differentiate among various subtypes of nonLangerhans cell histiocytosis. Proliferating histiocytes are usually negative for S-100 and CD1a and positive for HAM56 and factor XIIIa. ${ }^{6}$

JXG is mostly a self-limiting disease which regresses spontaneously. Cutaneous lesions may leave a residual atrophic or hyperpigmented scar. Extracutaneous involvement requires treatment. Excision is performed sometimes for diagnosis and aesthetic reasons.
Clinicians should be aware about different forms of JXG. Thus it can be diagnosed properly clinically and unnecessary investigations and surgical procedures can be avoided.

\section{Rukhsana Parvin}

Associate Professor

Department of Medicine

Enam Medical College \& Hospital, Savar, Dhaka

Email: rukhsana_parvin@yahoo.com

\section{Md. Rokon Uddin}

Associate Professor

Department of Skin \& VD

Enam Medical College \& Hospital, Savar, Dhaka

\section{References}

1. Cypel TKS, Zuker RM. Juvenile xanthogranuloma: case report and review of the literature. Can J Plast Surg 2008; 16(3): 175-177.

2. Dehner LP. Juvenile xanthogranuloma in the first decades of life. A clinicopathologic study of 174 cases with cutaneous and extracutaneous manifestations. Am J Surg Pathol 2003; 5: 579-593.

3. Adamson HG. Society intelligence: the dermatological society of London. Br J Dermatol 1905; 17: 222.

4. Püttgen KB. Juvenile xanthogranuloma (JXG). Available at: http://www.uptodate.com/contents/juvenilexanthogranuloma. Accessed July 2016

5. Margulis A, Lelin-Aldana H, Bauer BS. Juvenile xanthogranuloma invading the muscles in the head and neck: clinicopathological case report. Ann Plast Surg 2003; 50: 425-428.

6. Zelger B, Cerio R, Orchard G, Wilson-Jones E. Juvenile and adult xanthogranuloma. A histological and immunohistochemical comparison. Am J Surg Pathol 1994; 18: 126-135. 